\title{
Ayurvedic Management and Rehabilitation Therapy for Vardhakyajanya Badhirya
}

\author{
Dr. Ashwini Kumbar ${ }^{1}$, Dr. Suraj Kumbar ${ }^{2}$, Dr. A. M. Madni ${ }^{3}$ \\ ${ }^{1,2} \mathrm{PG}$ Scholar, ${ }^{3}$ Lecturer \\ ${ }^{1,3}$ Department of Shalakya Tantra, S. M. V. V's R. K. M. Ayurveda Medical College, \\ Hospital \& Research Centre, Vijayapur, Karnataka, India \\ ${ }^{2}$ Department of Panchakarma, SDM College of Ayurveda and Hospital, Hassan, Karnataka, India
}

\begin{abstract}
Karna is one among the important panchgyanendriya which perceives shabdha. These gyanendriya are acts like bridge for communication in social life. Badirya is a disease affecting Karna. Impairment in hearing mechanism is termed as badhirya when it affects elder age group it is called as Vardhakyajanya Badhirya. It is most common socio-medical disability. In modern it correlates to Presbyacusis -it is condition where there is progressive sensory hearing loss in bilateral and unilateral ear as the age progresses, which is associated with poor speech discrimination. It hampers the quality of life in elderly individual and leads to psychological disorders, depression, social isolation and loss of self-esteem.
\end{abstract}

Karna poorana is the main treatment modality which is explained in classics for karna rogas. Use of Balya(Nervine tonic) dravya in the form of sneha will alleviates the doshas and Rasayana chikitsa in older age group helps in prevention of rasadi dhatu kshaya. Allied science contributed aural rehabilitationHearing aids, Speech therapy etc which is not suitable for all and even some cannot offer those because of financial issues. Presbycusis is most common old age problem in developing countries after Arthritis and HTN. There is need of prevention, rehabilitation and Ayurveda chikitsa to overcome disability.

Keywords: Vardhakyajanya Bhadhirya, Presbyacusis, Rehabilitation, Karnapoorana

\section{INTRODUCTION}

Presbyacusis is "Hidden diability" as patient may or may not be aware of the hearing loss in initial stage. It is a sensorineural hearing loss associated with

increase in chronological age. It usually manifests after the age of $65 \mathrm{yrs}$ or even in earlier than 60 if there is predisposing risk factors. In Ayurveda Badhirya is described under Karna roga by Acharyas. Acharya Sushruta stated that vitiated Vata or Vata Kapha dosha causes margavarodha in shabdhavaha srotas leading to Badhirya ${ }^{1}$, when it affects at old age is called Vardhakyajanya Badhirya.

Presbyacusis affects more than half of adults by age of 75 years, most adults over the age of 80 , and nearly all adults who are $90 y$ rs or older. The WHO estimates that in 2025 there will be 1.2 billion people over 60years of age worldwide, with more than 500million individuals who will suffers significant impairment from Presbycusis ${ }^{2}$. As per Ayurveda, Badhirya manifests by vitiated vata dosha and in old age there is predominance of Vata dosha and also dhatu kshaya leads to Vardhakyajanya Bhadirya.

The risk factors for Presbyacusis includes Genetic factors, Environmental factors like -noisy environment, ototoxicity, systemic disease HTN,DM2 other metabolic disorders and inner ear damage through bad habits. As the age progresses there is degeneration of auditory nerve cells which leads to presbyacusis. Histopathloigically four distinct types have been described as per degenerative area by Schuknecht(1974). ${ }^{3}$

$>$ Neural presbyacusis- Degeneration of the cells of spiral ganglion, starting at the basal coil and progressing to the apex. There is high tone loss but speech discrimination is poor.

Sensory presbyacusis- Degeneration of the organ of corti, starting at the basal coil and progressing 
gradually to the apex. Higher frequencies are affected but speech discrimination remains good.

$>$ Strail/Metabolic- Atrophy of stria vascularis in all turns of the cochlea. Here physical and chemical process of energy production affected. Audigram is flat but speech discrimination is good.

$>$ Cochlear conductive- This is due to stiffening of the basilar membrane thus affecting its movements. Audiogram is sloping type.

Diagnosis of Presbaycusis includes history taking, examination and Audiometry i.e. screening and testing of central auditory system. Patients usually presents, Deafness-Gradual bilateral symmetrical and progressive hearing loss with varying degree, difficult to understand in a noisy environment and poor speech discrimination. Tinnitus-It is at initial stage accompanied with high frequency hearing loss. There will be Speech distortion along with recruitment (+/-).

Audiological testing like Pure tone audimetry and speech audiometry contributes in the diagnosis of Presbyacusis. The classic audiogram will shows a gradual sloping downwards pattern, as the frequency becomes higher the hearing gets worsen.

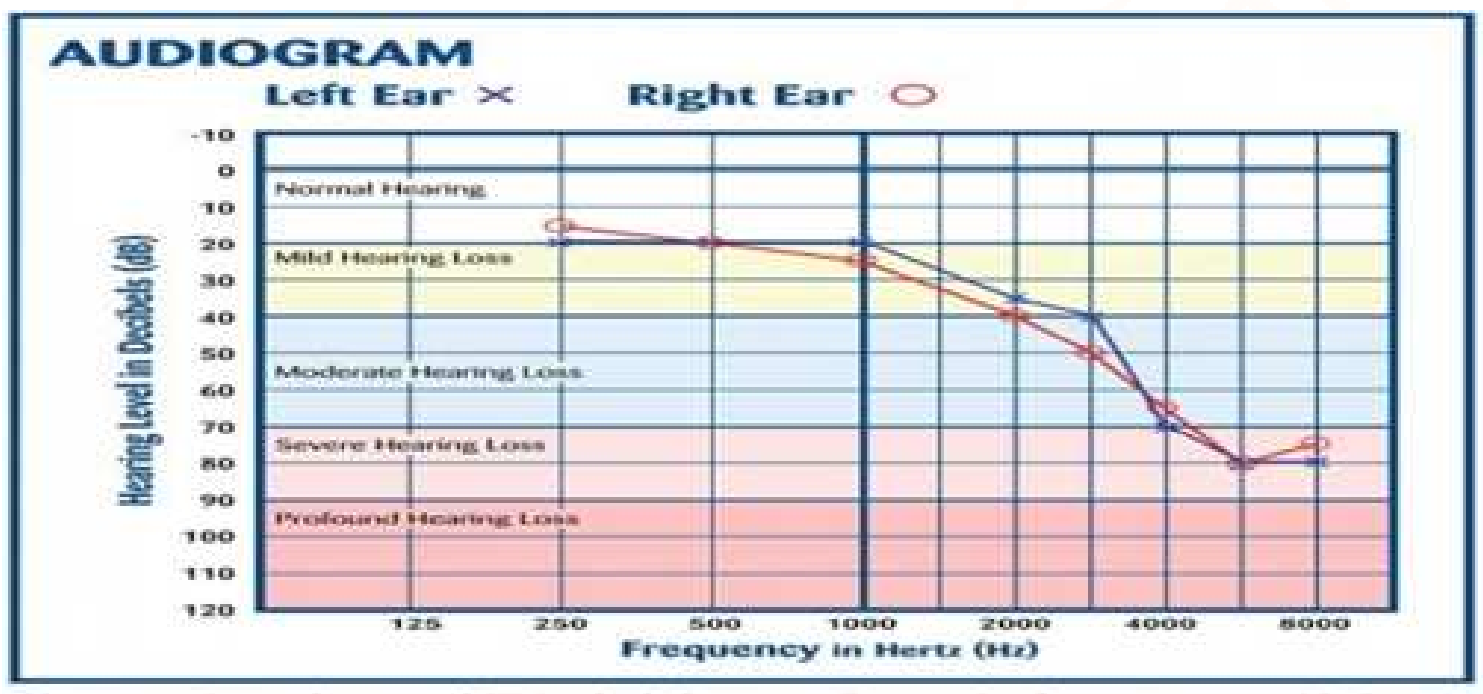

- Ar example presbyacusis (slopine tighi-froquerney hearing lows) syromymous wats the apeirug processs.

Hearing loss Assesment - WHO grades of hearing impairment ${ }^{4}$

\begin{tabular}{|l|c|l|}
\hline \multicolumn{1}{|c|}{$\begin{array}{c}\text { Grade of } \\
\text { mapirement }\end{array}$} & Audiometric ISO value & \multicolumn{1}{c|}{ Description } \\
\hline 0-No impairment & 25dBHL or less & Very slight hearing problem, able to hear whispers \\
\hline $\begin{array}{l}\text { 1-slight } \\
\text { impairment }\end{array}$ & 26-40dBHL & $\begin{array}{l}\text { Able to hear and repeat wors spoken } \\
\text { in normal voice at 1metre }\end{array}$ \\
\hline $\begin{array}{l}\text { 2-Moderate } \\
\text { impairment }\end{array}$ & 41-60dBHL & $\begin{array}{l}\text { Able to hear and repeat words } \\
\text { using raised voice at 1 metre }\end{array}$ \\
\hline $\begin{array}{l}\text { 3- Severe } \\
\text { impairment }\end{array}$ & $61-80 \mathrm{dBHL}$ & $\begin{array}{l}\text { Able to hear some words when } \\
\text { Shouted into better ear. }\end{array}$ \\
\hline $\begin{array}{l}\text { 4-Profound } \\
\text { impairment }\end{array}$ & 81dBHL or greater than that & $\begin{array}{l}\text { Unable to hear and understand } \\
\text { Even a shouted voice. }\end{array}$ \\
\hline
\end{tabular}

Prevention is better than treating Presbyacusis as the aging is irreversible and inevitable process in life and it leads to social isolation, feeling of social inferiority even they suffers from pshycological illness like depression as the aged people depends on hearing to overcome other disabilities at old age. Prevention includes avoidance of noisy environment; reduce the gunshooting and high frequency music sounds. One should go under routine systemic health check up to focus on risk factors and taking treatment for it.

Aural rehabilitation is adopted in Age related sensory neural deafness, It includes diagnosis and implementation of different types of hearing rehabilitations. 
$>$ Hearing aids- There are many varieties of hearing aids are available which is used on the basis of type and configuration of hearing loss. Air conduction hearing aid ,Bone conduction hearing aid which includes BTE,ITE and CIC these are used in mild to moderate hearing loss.

$>$ Cochlear implants- These are electrical devices which are used in profoundly deaf patients. It is useful in hearing and improves communication ability.

$>$ Auditory Brainstem Implants- It stimulate the cochlear nuclear complex in the brainstem directly by placing the implant in lateral recess of the $4^{\text {th }}$ ventricle. It is used in neurofibromatosis, Vestibular Schwannoma. This implants has got limitation now a days as they are in constant technological development.

> Speech reading- Understanding speech by using visual cues like movement of lips, facial expression, gesture and probable context of conversation.

$>$ Auditory training-Teaching an individual to recognize speech sounds, patterns, words, phrases or sentences via audition.

$>$ Manual comminucation- Teaching comminucation via finger-spelling and with a sign language.

Hearing aids are not actual solution for presbyacusis because it has following disadvantages

$>$ Cost effective

$>$ Recurrent infections of external auditory canal and middle ear.

> Choclear implants may cause, Facial nerve palsy, Device failure, post op Vertigo, Meningitis and extrusion/ exposure of device.

Ayurveda has great role for preventing geriatric disorders and the many reaserches shown that effective results in treating Vardhakyanadi Badhirya. Karna pooran (instillation of medicated dravya in External auditory canal) is prime and unique treatment modality adopted for Karna rogas. Acharya Charaka ,Acharya Vagbhata advised to take daily Karna poorana for preventing ear disease. Acharya Sushruta has explained Karnapoorana in swastavritta Adhyaya.

\section{The effects of Karnapoorana in the management of Badhirya ${ }^{6}$}

$>$ Karnapoorana reduces the frequency of sound by reflecting and refraction of sound. Because sounds frequency and pressure changes from one medium to other medium thus its frequency reduces and disability decreases.

$>$ According to Ayurveda Karna ia a location of Vayu and Akash mahaboota, oil reduce the rukshata of Vata and create a media.

$>$ Smooth walls have tendency to direct sound waves in a specific direction Karnapoorana also smoothing the inner wall.

$>$ It helps to maintain the cilia of inner ear cells which are responsible for hearing.

$>$ Karna pooran also helps to remove the wax and also protect ear from fungus and many other disease.

Bilva taila, Apamarga kshara taila, Bilvadi taila Lashunadi Taila, Dashamooladi Taila Karna poorana ${ }^{7}$ is indicated in vardhakyanadi Badhirya. As the Badhirya is manifestated because of vitiated Vata and Kapha dosha in karnanadi the dravyas which are having Vata kaphahara property are used for instillation. Taila reduces rukshata and creates media for sounds. Purvakarma like Karna abhyanga with murchita tila taila which has the Vikasi, Sukshma, Vishad, Guru and Sara properties it also as Bhrihana so nourishment of Shravanendriya improves hearing mechanism. Bashpa sweda aids the quick absorption of Oil thus increases blood circulation to ears. ${ }^{8}$

Shamana chikitsa which includes Rasayana chikitsa, as Badhirya manifests in Vardhakya, Rasayana and Bhrihamna prevents further depletion of Dhatus and nourishes Nerves. Induvati, Sarivadi Vati, Ashwagandha churna and Yogaraja Guggulu helps in pacifying the Vata dosha and strenghthen weakened nerves.

\section{Conclusion:}

Vardhakyajanya Badhirya is more common among elder people now days because of more exposure to noisy environment, hereditary factors and along with risk factors contributes more. Diagnosis made on the base of history taking and Audiometry testing. Aural rehabilitation and its manangement in modern science has got limitation. The hearing devices are not suitable for all in such cases along with aural rehabilitation Prevention through dinacharya and Ayurveda chikitsa it can be managed. Karnapoorana is effective treatment in Badhirya along with Rasayana, Balya and Bhrihmaneeya Dravya. 


\section{References}

1. Sushruta, Sushruta Samhita, Uttaratantra, Karnagata roga vigyaniyam Adhyaya,20/8, Edited From Beginning To 9th Adhyaya Of Chikitsastana By Jadavji Trikamji Acharya And The Rest By Narayan Ram Acharya Kavyatirtha, Chaukhambha Orientalia, Varanasi, Reprint: 2012

2. Nikolas H Belvins, MD, Presbyacusis upto date http://www.uptodate.com.

3. P. L Dingra. Shruti Dingra; Diseases of Ear, Nose and Throat \& Haed and Neck surgery. Red Elsevier India Private Limited Reprinted-20142015. $5^{\text {th }}$ chapter Hearing Loss. Page No 38.

4. Gajanan B. vPatil Phd Scholor, Bharati Vidyapeeta College of Ayurveda Pune, Maharastra, India. Review on Age Related
Sensori-Neural Deafness (Badhirya) and its Ayurvedic Approach. Asian Journals of Multidisciplinary Studies. Vol4.

5. Aural Rehabilitation, @ Wikipedia en.wikipedia.org/wiki/Aural_rehabilitation.

6. Rjiv Amal, Jigisha Patel, Haridra Dave: A conceptual Study of Karnapoorana in Prevention of Nihl (Noise Induced Hearing Loss): International Journal of Medical Science and Clinical Inventions Volume 3.

7. Shee Govinda Das, Bhaishajya Ratnavali Volume2, Karna roga chikitsa adhyaya 62 chapter.

8. Savita S. Angadi and Vijayakumar S. Kotrannavar: A case discussion on Presbyacusis: Journal of Auyrveda and Integrative Medicine. Elsevier. 